\title{
Environmental Surveillance for SARS-CoV-2 in Two Restaurants from a Mid-scale City that Followed U.S. CDC Reopening Guidance
}

Special Issue:

Special Issue on Air Quality in a Changed World: Regional, Ambient, and Indoor Air Concentrations from the COVID to Post-COVID Era (II)

\section{OPEN ACCESS}

Received: November 7, 2021 Revised: November 23, 2021 Accepted: November 30, 2021

${ }^{*}$ Corresponding Author: cywu@ufl.edu

\section{Publisher:}

Taiwan Association for Aerosol Research

ISSN: $1680-8584$ print ISSN: 2071-1409 online

(c) Copyright: The Author(s) This is an open access article distributed under the terms of the Creative Commons Attribution License (CC BY 4.0), which permits unrestricted use, distribution, and reproduction in any medium, provided the original author and source are cited.

\section{Hongwan $\mathrm{Li}^{1}$, Sripriya Nannu Shankar ${ }^{1}$, Chiran T. Witanachchi ${ }^{1}$, John A. Lednicky,3, Julia C. Loeb ${ }^{2,3}$, Md. Mahbubul Alam ${ }^{2,3}$, Z. Hugh Fan ${ }^{4,5}$, Karim Mohamed ${ }^{5}$, Jessica A. Boyette ${ }^{1}$, Arantzazu Eiguren-Fernandez ${ }^{6}$, Chang-Yu Wu ${ }^{{ }^{*}}$}

\author{
${ }^{1}$ Department of Environmental Engineering Sciences, University of Florida, USA \\ ${ }^{2}$ Department of Environmental and Global Health, University of Florida, USA \\ ${ }^{3}$ Emerging Pathogens Institute, University of Florida, USA \\ ${ }^{4}$ Department of Mechanical \& Aerospace Engineering, University of Florida, USA \\ ${ }^{5} \mathrm{~J}$. Crayton Pruitt Family Department of Biomedical Engineering, University of Florida, USA \\ ${ }^{6}$ Aerosol Dynamics Inc., Berkeley, California, USA
}

\section{ABSTRACT}

Since mask use and physical distancing are difficult to maintain when people dine indoors, restaurants are perceived as high risk for acquiring COVID-19. The air and selected environmental surfaces in two restaurants in a mid-scale city located in north central Florida that followed the Centers for Disease Control and Prevention (CDC) reopening guidance were sampled three times from July 2020 to February 2021. Sixteen air samples were collected for 2 hours using air samplers, and 20 surface samples by using moistened swabs. The samples were analyzed by real-time reverse transcriptase-polymerase chain reaction (RT-PCR) for the presence of SARS-CoV-2 genomic RNA. A total of $\sim 550$ patrons dined in the restaurants during our samplings. SARS-CoV-2 genomic RNA was not detected in any of the air samples. One of the 20 surface samples (5\%) was positive. That sample had been collected from a plastic tablecloth immediately after guests left the restaurant. Virus was not isolated in cell cultures inoculated with aliquots of the RT-PCR-positive sample. The likelihood that patrons and staff acquire SARS-CoV-2 infections may be low in restaurants in a mid-scale city that adopt $\mathrm{CDC}$ restaurant reopening guidance, such as operation at $50 \%$ capacity so that tables can be spaced at least 6 feet apart, establishment of adequate mechanical ventilation, use of a face covering except while eating or drinking, and implementation of disinfection measures.

Keywords: COVID-19, Air sampling, Surface, Hospitality, Infection risk

\section{INTRODUCTION}

Severe acute respiratory syndrome coronavirus 2 (SARS-CoV-2) is the causative agent of the coronavirus disease (COVID-19) pandemic. It can be shed by infected individuals including those that are pre-symptomatic and asymptomatic as they breath, speak, cough, or sing (Ma et al., 2021; Pan et al., 2020). Therefore, places where facemask use and physical distancing are difficult to maintain, such as restaurants that offer on-site eating or drinking, may pose a relatively high risk for acquiring COVID-19 infections. Accordingly, various epidemiological studies traced COVID-19 outbreaks to dining in restaurants during the early pandemic. For example, ten infected persons within three different clusters had indirect contact with an index case when they dined in a restaurant in Guangzhou, China, on January 24, 2020 (Li et al., 2020). Similarly, three cases were investigated wherein patrons in separate tables dined near an index case in a restaurant in Korea 
on June 17, 2020 (Kwon et al., 2020). Notably, several individuals in both outbreaks were infected even though the distance between them and the index case was greater than $2 \mathrm{~m}$ (i.e., physical distancing was followed). Environmental modelling studies using computational fluid dynamics (CFD) simulations also suggest the transmission can occur in poorly ventilated restaurants even though physical distancing is maintained (Liu et al., 2021; Lu et al., 2020). Another case investigation inferred that full-service restaurants can be particularly risky for people acquiring COVID-19, based on human mobility data in Chicago from March-April 2020 (Chang et al., 2020). Noteworthy, the largest state medical society in the U.S., the Texas Medical Association, ranked the risk level of acquiring COVID-19 as moderate-high for dining in restaurants during the pandemic (Texas Medical Association, 2020).

On the basis of relatively high infection risk inferred from epidemiological and environmental modelling studies, restaurants across the U.S. were forced to close or were only allowed to provide take-out and delivery services during the business lockdown period that spanned March to April of year 2020 (Kim and Lee, 2020). The reopening of restaurants occurred gradually in all states in the U.S. by mid-June 2020, with take-out and/or dine-in services (Guy et al., 2021), in consideration of the following factors: (a) rapid development of COVID-19-related knowledge through intensive research efforts, which then resulted in a better understanding of the transmission of SARS-CoV-2 and development of effective strategies to minimize transmission of the virus, (b) the desire by a substantial majority of consumers to engage in social and physical interactions, such as dining out more frequently at restaurants (Sung et al., 2021), (c) restaurant visits by patrons had declined by $75 \%$ in the U.S. by March 2020 (Santos, 2020), and prediction that over half of restaurants would not survive the pandemic if they were maintained at lock-down status (Kim and Lee, 2020). To assist restaurants in reopening, the Centers for Disease Control and Prevention (CDC) provided reopening guidance that included operation at reduced capacity, modification of seating layouts to ensure customer parties remain at least 6 feet apart, implementation of disinfection measures, and requirements that both restaurant employees and patrons wear face coverings when not eating or drinking (CDC, 2020). However, after the lockdown was lifted, epidemiological studies (Fisher et al., 2020) revealed that in the U.S. people engaging in on-site dining activities in restaurants had significantly higher positive rates for SARS-CoV-2 than those not exposed to restaurant dining environments $(p=0.01)$. In contrast, the same study found no statistical correlation of positive rates due to activities in shopping centers, public transportation, or salons $(p>0.05)$. Additionally, significant increases in the number of COVID-19 cases and death rates were associated with the reopening of full-service restaurants from March to December 2020 (Guy et al., 2021).

Environmental surveillance consisting of air and surface sampling can be used to evaluate the risk of acquiring COVID-19 in restaurant environments through detection of SARS-CoV-2, since infected individuals including those who are pre-symptomatic and asymptomatic can spread the virus in aerosols $(\leq 5 \mu \mathrm{m})$ and/or droplets (>5 $\mu \mathrm{m})$ (CDC, 2021; Harvey et al., 2021a). However, thanks to the challenges of getting restaurants that would allow sampling in their facilities, there have been very few sampling studies focused on restaurant environments. The perception of high risk for acquiring COVID-19 in restaurants is derived from epidemiology studies without actual field samplings.

During the early period of the pandemic, environmental samplings were mainly conducted in healthcare facilities with COVID-19 patients to investigate the transmission routes, and the detection of SARS-CoV-2 in the air was reported in intensive care units (ICU), isolation rooms, and hospital rooms (Chia et al., 2020; Lednicky et al., 2020a), as well as in retail stores, hallways, and entrances within hospitals (Liu et al., 2020; Santarpia et al., 2020). Surface samples collected from high-touch surfaces of medical centers, isolation locations, and residential homes with COVID-19 patients were also positive for SARS-CoV-2 (Ben-Shmuel et al., 2020; Chia et al., 2020; Maestre et al., 2021). Later on, sampling measurements for SARS-CoV-2 were focused on public spaces in attempts to identify locations in the community that might have high potential of transmission risk, so that resources dedicated to preventive measures could be concentrated in those areas. Examples were studies focused on detection of SARS-CoV-2 in the air of shopping centers, subway stations, and buses that were performed during June-July 2020 in Iran (Hadei et al., 2021) and on the public surfaces of subway trains, buses, grocery stores, and banks in densely populated metropolitan areas in Brazil, Spain, and the U.S. (Abrahão et al., 2021; Harvey et al., 2021a; Moreno et al., 2021). In comparison, there were limited studies conducted in mid-or small- scale cities, 
but assessing the infection risk in smaller cities should not be neglected. Many studies also reported the presence of SARS-CoV-2 on the surfaces of ventilation grates and filters in buildings with COVID-19 patients, since a large volume of room air passes through the heating, ventilation, and air conditioning (HVAC) filters (Guo et al., 2021; Maestre et al., 2021; Santarpia et al., 2020). On the other hand, negative sampling results may reflect the effectiveness of the reopening measures adopted by certain entities to lower the risk of acquiring SARS-CoV-2 infections, exemplified by negative air and surface samples collected from clinics in Hong Kong and public buses in Italy. Lack of detection of SARS-CoV-2 in those studies were likely a result of improvements to ventilation systems, mandatory face coverings, and enhanced disinfection strategies (Carloid et al., 2020; Cheng et al., 2020). As illustrated in aforementioned studies, environmental sampling is an effective means for detecting SARS-CoV-2 in the air and surfaces and evaluating the risk of acquiring infections in the sampled areas. Therefore, we collected air and surface samples in two restaurants in a mid-scale city in the U.S., aiming to assess the infection risk in these indoor dining settings and to investigate the effectiveness of reopening measures adapted by them to minimize the risk of acquiring COVID-19 in mid-scale cities with a lower population density.

\section{METHODS}

\subsection{Study Setting}

This present study was conducted in two restaurants ( $A$ and $B$ ) located in an urban/suburban mix area of north-central Florida (FL), U.S.A. The mid-scale city where the restaurants are located has a population density of 2055 people per square mile (i.e., 793 people per square kilometer) (Best Places, 2021). The number of COVID-19 cases in FL were within the top 3 among all the states in the U.S. during the sampling periods (Statista, 2021). Fig. 1 shows the number of positive COVID-19 cases in the county during our sampling campaign and the six sampling event dates. Restaurant A was visited from July-August 2020, when FL was at Phase 2 for reopening and up to $50 \%$ of indoor seating capacity was allowed at restaurants. Restaurant B was sampled from January-February 2021, when FL was in Phase 3 for reopening starting September 25, 2020. It was still reopened at $50 \%$ capacity although seating/occupation restrictions were already lifted in those restaurants that implemented reopening protocols. They were both mechanically airconditioned, one-floor buildings without open windows. The areas of Restaurants $A$ and $B$ are $180 \mathrm{~m}^{2}(12 \mathrm{~m} \times 15 \mathrm{~m})$ and $204 \mathrm{~m}^{2}(12 \mathrm{~m} \times 17 \mathrm{~m})$, respectively, and their layouts are shown in Fig. 2. The number of patrons during sampling periods are listed in Table 1 . Since only air and surface samples were collected in our study and no human subjects were involved in the conduct of this research, approval from the institutional review board (IRB) was not required.

\subsection{Air Sampling}

As shown in Fig. 2, for all the air samples collected in Restaurant A, a Vlable Virus Aerosol

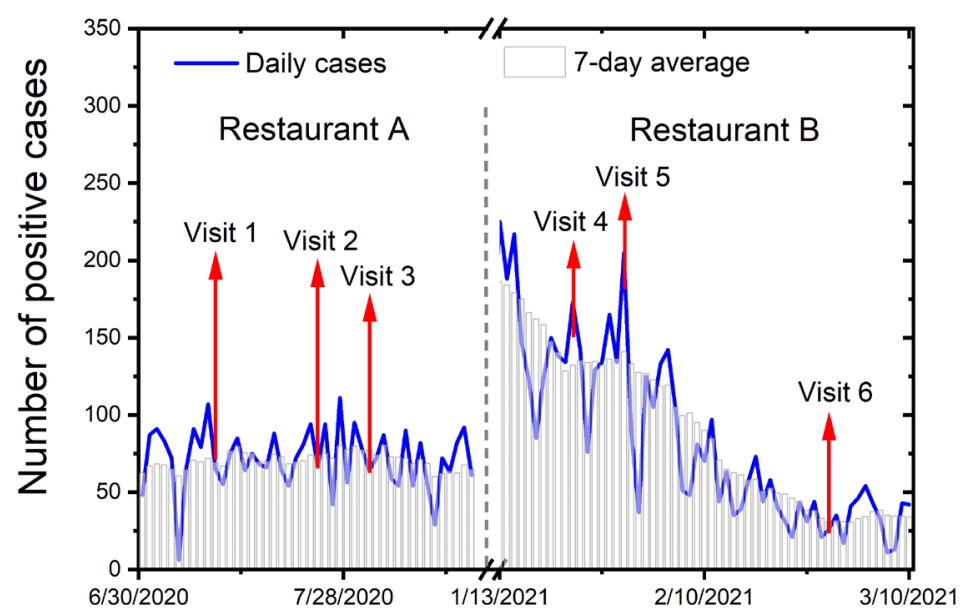

Fig. 1. Number of positive COVID-19 cases in Alachua county, FL and six sampling event dates. 

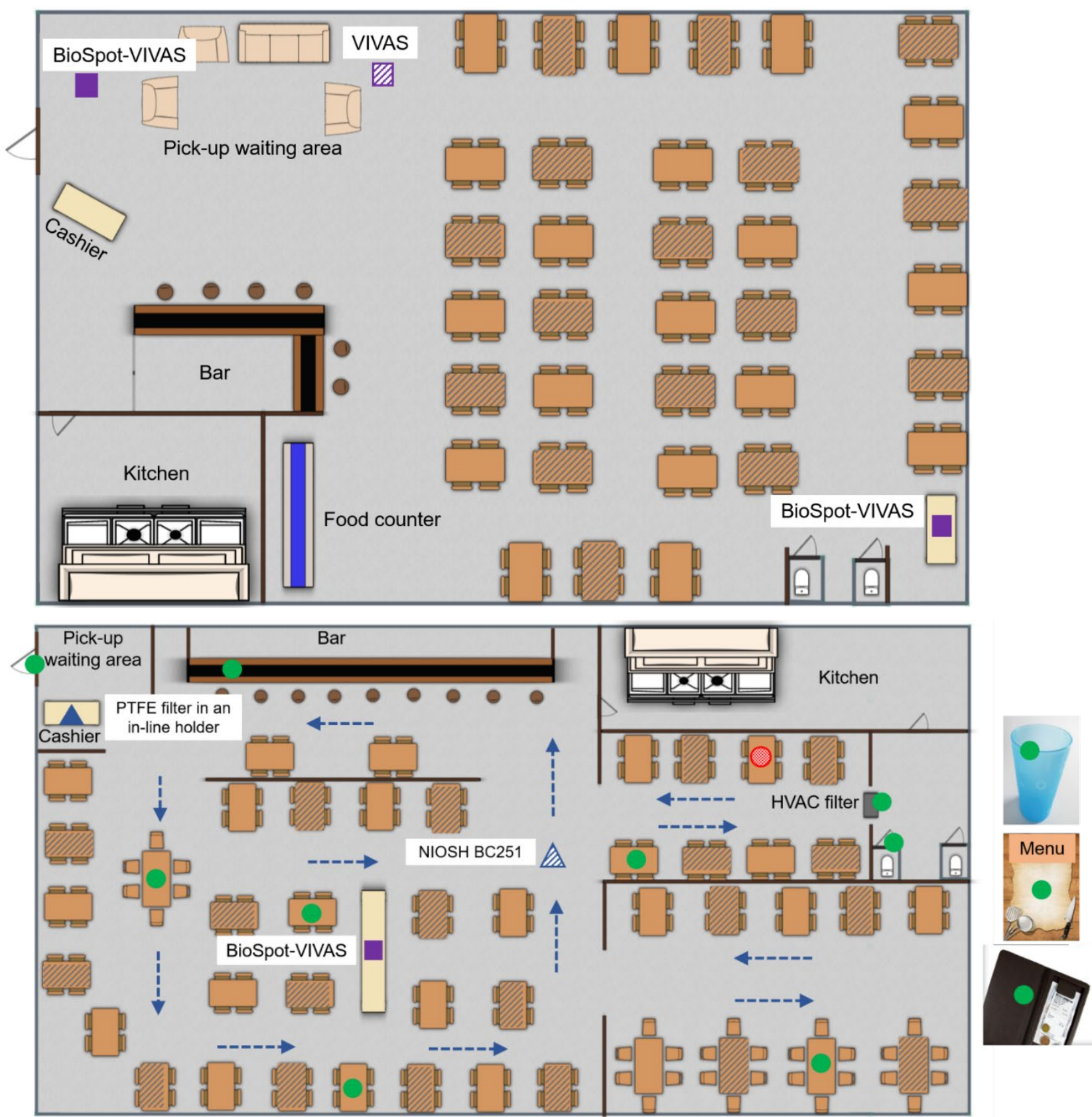

\begin{tabular}{|cl|}
\hline & BioSpot-VIVAS \\
& VIVAS \\
& PTFE filter in an in-line holder \\
--- & NIOSH BC251 \\
0 & Sampling path (NIOSH BC251) \\
Surface swab positive \\
Suce swab negative \\
Opened table \\
\hline Closed table
\end{tabular}

Fig. 2. Sampling locations in (a) restaurant $A *$ and (b) restaurant $B$ that both reopened at less than $50 \%$ capacity. * The BioSpotVIVAS was placed in one of the indicated locations during sampling and details are listed in Table 1. 
Table 1. SARS-CoV-2 rRT-PCR results of air and surface samples collected at two restaurants.

\begin{tabular}{|c|c|c|c|c|c|c|}
\hline & Date & $\begin{array}{l}\text { Number } \\
\text { of patrons }\end{array}$ & Type of sample & Sampling locations & $\begin{array}{l}\text { Number } \\
\text { of samples }\end{array}$ & $\begin{array}{l}\text { Positivity } \\
\text { rate }\end{array}$ \\
\hline \multirow[t]{4}{*}{$A$} & $7 / 11 / 2020$ & 125 & Air (BioSpot-VIVAS) & Near cashier & 2 & $0 / 2$ \\
\hline & $7 / 25 / 2020$ & 135 & Air (BioSpot-VIVAS) & Dining area & 2 & $0 / 2$ \\
\hline & $8 / 1 / 2020$ & 102 & Air (VIVAS) & Near pick-up waiting area & 1 & $0 / 1$ \\
\hline & & & Air (BioSpot-VIVAS) & Dining area & 1 & $0 / 1$ \\
\hline \multirow[t]{19}{*}{ B } & $1 / 23 / 2021$ & 70 & Air (BioSpot-VIVAS) & Dining area & 1 & $0 / 1$ \\
\hline & & & $\begin{array}{l}\text { Air (PTFE filter in an } \\
\text { in-line holder) }\end{array}$ & Near cashier & 1 & $0 / 1$ \\
\hline & & & Surface swab & Entrance door handrail & 1 & $0 / 1$ \\
\hline & & & Surface swab & $\begin{array}{l}\text { Table surface after use and prior to } \\
\text { cleaning/disinfection }\end{array}$ & 2 & $1 / 2$ \\
\hline & & & Surface swab & $\begin{array}{l}\text { Bar counter surface after use and prior to } \\
\text { cleaning/disinfection }\end{array}$ & 1 & $0 / 1$ \\
\hline & & & Surface swab & Restroom door handrail & 1 & $0 / 1$ \\
\hline & $1 / 30 / 2021$ & 55 & Air (BioSpot-VIVAS) & Dining area & 1 & $0 / 1$ \\
\hline & & & Air (NIOSH BC251) & $\begin{array}{l}\text { Personal sampler throughout the } \\
\text { restaurant }\end{array}$ & 3 & $0 / 3$ \\
\hline & & & Surface swab & Menu after use and prior to disinfection & 2 & $0 / 2$ \\
\hline & & & Surface swab & $\begin{array}{l}\text { Cup after use and prior to } \\
\text { cleaning/disinfection }\end{array}$ & 2 & $0 / 2$ \\
\hline & & & Surface swab & HVAC filter & 1 & $0 / 1$ \\
\hline & & & Surface swab & HVAC vent grate & 1 & $0 / 1$ \\
\hline & $2 / 27 / 2021$ & 65 & Air (BioSpot-VIVAS) & Dining area & 1 & $0 / 1$ \\
\hline & & & Air (NIOSH BC251) & $\begin{array}{l}\text { Personal sampler throughout the } \\
\text { restaurant }\end{array}$ & 3 & $0 / 3$ \\
\hline & & & Surface swab & Restroom door handrail & 1 & $0 / 1$ \\
\hline & & & Surface swab & Entrance door handrail & 1 & $0 / 1$ \\
\hline & & & Surface swab & $\begin{array}{l}\text { Table surface after use and prior to } \\
\text { cleaning/disinfection }\end{array}$ & 4 & $0 / 4$ \\
\hline & & & Surface swab & $\begin{array}{l}\text { Check-out card holder after use and prior } \\
\text { to disinfection }\end{array}$ & 2 & $0 / 2$ \\
\hline & & & Surface swab & $\begin{array}{l}\text { High chair after use and prior to } \\
\text { cleaning/disinfection }\end{array}$ & 1 & $0 / 1$ \\
\hline \multicolumn{5}{|c|}{ Total air samples } & 16 & $0 / 16$ \\
\hline \multicolumn{5}{|c|}{ Total surface swab samples } & 20 & $1 / 20$ \\
\hline
\end{tabular}

Sampler (VIVAS) and a BioSpot-VIVAS (Aerosol Devices Inc., Fort Collins, CO) were used, and the air intakes were positioned $\sim 1.5 \mathrm{~m}$ above the floor. The samplers were situated near the cashier, pick-up waiting area, or dining area. At these testing sites, all patrons traversed by the samplers on their way to/from their tables. Moreover, the samplers were also near some tables where patrons were eating or drinking without face covering. A $2 \mathrm{~h}$ air sampling at $8 \mathrm{~L} \mathrm{~min} \mathrm{~m}^{-1}$ each was conducted during lunch and dinner time. The BioSpot-VIVAS is a commercial version of VIVAS, and they were previously used to successfully collect viable SARS-CoV-2 in the air of hospital rooms with COVID-19 patients (Lednicky et al., 2020b) and other respiratory viruses (e.g., influenza A H1N1 and H3N2 viruses and influenza B viruses) in a student health care center (Pan et al., 2017). Both the BioSpot-VIVAS and VIVAS operate by a laminar flow water-based condensation method to gently collect airborne particles, whose original dimensions get enlarged through surface deposition of water molecules, onto a $35 \mathrm{~mm}$ Petri dish containing $1.5 \mathrm{~mL}$ of liquid collection medium (LCM). The four major sections of the device are the conditioner, initiator, moderator, and collector, which were operated at $4^{\circ} \mathrm{C}, 40^{\circ} \mathrm{C}, 28^{\circ} \mathrm{C}$, and $25^{\circ} \mathrm{C}$, respectively. The $\mathrm{LCM}$ consisted of sterile $1 \times$ brain-heart infusion broth without dextrose (Thermo Fisher Scientific, Carlsbad, CA) that had been supplemented with cell culture grade neomycin sulfate $\left(0.4 \mathrm{mg} \mathrm{mL}^{-1}\right.$ ) (Sigma 
Aldrich, St. Louis, MO), cell culture grade amphotericin B $\left(2.5 \mu \mathrm{g} \mathrm{mL}^{-1}\right)$ (Sigma Aldrich), a final concentration of $0.2 \mathrm{M}$ cell culture grade sucrose $\left(68.46 \mathrm{~g} \mathrm{~L}^{-1}\right)$, and bovine albumin fraction $\mathrm{V}$ $\left(4 \mathrm{~g} \mathrm{~L}^{-1}\right)$ (Thermo Fisher Scientific).

In Restaurant B, the BioSpot-VIVAS was placed in the dining area to collect air samples at $8 \mathrm{~L} \mathrm{~min}^{-1}$ for $2 \mathrm{~h}$ during dinner time (Fig. 2). Additionally, a filter in an in-line holder collected air samples near the cashier. A $5 \mu \mathrm{m}$ pore size 47-mm PTFE membrane filter (catalog no. LSWP04700, Millipore Sigma, US) that had collected respiratory viruses such as SARS in air samples (Rahmani et al., 2020) was used in the samplings. To investigate the spatial-weighted average of virus aerosol concentrations, a NIOSH BC 251 bioaerosol sampler (US National Institute for Occupational Safety and Health), which had collected SARS-CoV-2 in the air of hospital rooms with COVID-19 patients (Lei et al., 2020) was clipped onto a masked sampling team member who walked throughout the dining area of Restaurant B (Fig. 2). The air inlet was vertically held at a height corresponding to the breathing zone of the sampling team member. The airborne particles were collected into three size fractions: $>4.4 \mu \mathrm{m}$ in a $15-\mathrm{mL}$ tube (Falcon conical centrifuge tube, catalog no. 14-959-53A, Fisher Scientific, Waltham, MA), 1.1-4.4 $\mu \mathrm{m}$ in a $1.5 \mathrm{~mL}$ Eppendorf tube (Microcentrifuge tubes, catalog no. 02-681-373, Fisher Scientific), and $<1.1 \mu \mathrm{m}$ on a $2 \mu \mathrm{m}$ pore size 37-mm diameter PTFE membrane filter (catalog no. 225-1709, SKC Inc., Eighty Four, PA). Both the PTFE filter in an in-line holder and NIOSH BC 251 were each connected to a Zefon sampling pump (Zefon International, Inc., Ocala, $\mathrm{FL}$ ) at $3 \mathrm{~L} \mathrm{~min}^{-1}$ for $2 \mathrm{~h}$ air samplings.

After sampling, all collected air samples were placed in a Styrofoam cooler (interior: $25 \mathrm{~cm} \times$ $20 \mathrm{~cm} \times 18 \mathrm{~cm}$ ) containing two ice packs. The cooler was subsequently transported to a BSL2enhanced laboratory for initial work-up. There, the filters with collected airborne particles were aseptically retrieved from the collectors and immersed in sterile $1.5 \mathrm{~mL}$ of LCM. For the centrifuge tubes of the NOISH bioaerosol sampler, $0.5 \mathrm{~mL}$ of LCM was added to the $1.5-\mathrm{mL}$ tube, and $1.5 \mathrm{~mL}$ to the $15-\mathrm{mL}$ tube, and the tubes were gently mixed to resolubilize materials collected on the surfaces. All the Petri dishes, filters, and centrifuge tubes were stored in a locked $-80^{\circ} \mathrm{C}$ freezer until further analyses.

\subsection{Surface Sampling}

Moistened flocked nylon swabs were used to collect samples in Restaurant B from surfaces that were frequently touched by patrons, such as the entrance and restroom door handrails. Swab samples were also collected from surfaces contacted closely by individual patrons (Fig. 2), such as table tops, drinking utensils, and menus. For the objects used by the patrons during eating or drinking, surface swabs were collected immediately after use and prior to cleaning and disinfection of the tables after the patrons left. Surface swab samples were additionally collected from ventilation grates and HVAC filters. When possible, a surface area of $25 \mathrm{~cm} \times 25 \mathrm{~cm}$ was swabbed, such as the filter and table surface; for surfaces that were difficult to measure the dimensions, the entire surface was sampled, such as the door handrails and drinking utensils. Immediately following sampling of any surface, swabs were inserted into $1.5 \mathrm{~mL}$ of sterile LCM in transport tubes. The transport and storage of the surface swabs followed the general process used for air samples.

\subsection{Laboratory Analyses}

The presence of SARS-CoV-2 genomic RNA (vgRNA) in air and surface samples was determined by real-time reverse transcriptase-quantitative polymerase chain reaction ( $R$ RT-qPCR) as detailed in Lednicky et al. (2020a). This method has been used to detect SARS-CoV-2 vgRNA in human specimens such as nasopharyngeal, throat, and saliva samples, and in environmental samples (Lednicky et al., 2020a, b, 2021a). Cell lines consisting of LLC-MK2 (Rhesus monkey kidney cells, catalog no. ATCC CCL-7) and Vero E6 cells (African green monkey kidney cells, catalog no. ATCC CRL-1586) were used for SARS-CoV-2 isolation attempts, as described in Lednicky et al. (2021b). These cell lines are susceptible and permissive for the virus and have been used by the authors to isolate SARS-CoV-2 from the air of hospital rooms with COVID-19 patients (Lednicky et al., 2021c) and from clinical and environmental samples (Lednicky et al., 2021a; Nelson et al., 2021; Schaller et al., 2021). A quantitation cycle (Cq) value of 39.15 or greater is considered negative for detection for SARS-CoV-2 in this study (Lednicky et al., 2020a, 2021b, c; Nelson et al., 2021). 


\section{RESULTS AND DISCUSSION}

\subsection{Sampling Results}

During the six sampling events, there were approximately 550 patrons dining in the restaurants, with an average of 120 and 63 patrons for each measurement in Restaurants $A$ and B, respectively (Table 1). In total, 16 air samples and 20 surface samples were collected (Table 1). Only 1 of 20 surface samples $(5 \%)$ tested positive (Cq value $<39.15$ ) for SARS-CoV-2 vgRNA (Fig. 2 ) and that was collected from a tablecloth surface in sampling visit 4 at Restaurant $B$. There was no cytopathic effect induced by the positive surface sample on cell culture, and vgRNA was not detected in the cultures by rRT-qPCR. None of the six air samples of Restaurant $A$ or ten air samples of Restaurant B was positive for SARS-CoV-2 vgRNA, including the air samples collected simultaneously with the positive tablecloth surface sample.

Since the two restaurants reopened, their managers were not aware of any claims by any employees that they acquired COVID-19 while working there. We were unable to test patrons for SARS-CoV-2 and have no way of knowing whether any patrons developed SARS-CoV- 2 infections after dining in either of the two restaurants. SARS-CoV-2 was not detected in any air samples suggesting that the airborne transmission risk might have been low in the sampled restaurants at the time the samplings were performed. Fig. 1 shows that on average there were $\sim 80$ cases per day in Alachua county. In a conservative scenario that only symptomatic individuals were tested for SARS-CoV-2 and assuming that $\sim 40 \%$ of infected individuals may be pre-symptomatic or asymptomatic (Oran and Topol, 2020), the daily active cases of pre-symptomatic or asymptomatic individuals might be 53 cases that could potentially spread the virus when dining in the restaurants. Considering the population in Alachua county of $\sim 270,000$, the rate of pre-symptomatic and asymptomatic individuals in the population was $\sim 0.02 \%$ during the sampling periods, implying that 0.1 positive patrons might have visited the restaurants during samplings, considering there was a total of $\sim 550$ patrons. The adopted CDC reopening guidance and the low active rates may both contribute to the low positive samples in the present study, and that may be the condition commonly encountered in a mid-scale city.

Negative test results attained after rRT-qPCR analyses of surface samples of the vent grates and HVAC filters further suggest the possibility of acquiring SARS-CoV-2 infection through inhalation exposures was low in the restaurants at the time our tests were performed. However, in the early pandemic when there was no operation guidance against SARS-CoV-2 transmission, an outbreak involved people infected at $6.5 \mathrm{~m}$ away from the index case with 5-min exposures in a restaurant (Kwon et al., 2020). Instead of central air HVAC systems used in the restaurants visited in this study, that restaurant utilized a ceiling-type air conditioner, which facilitated transport of the emitted virus-laden aerosols horizontally from the index case to other patrons downwind in poorly ventilated indoor spaces (Blocken et al., 2020). Using a mechanical ventilation (i.e., HVAC systems) is an improvement because it can quickly pull exhaled air into the ventilation system and exhaust that outside, thus minimizing airborne transmission of SARS-CoV-2 inside. Similarly, in long-term care facilities, positive SARS-CoV-2 vgRNA detection rates were relatively higher among surface samples collected in rooms with passive ventilation, compared to those collected in mechanically ventilated rooms (Dumont-Leblond et al., 2021). Since those samples were swabbed from the surfaces that were out of reach and infrequently cleaned, the detection of SARS-CoV-2 in the samples was more likely due to the virus-laden airborne particles settling down on the surfaces, instead of fomite transmission. In the sampled restaurants, the apparent lack of easily detectable SARS-CoV-2 vgRNA was likely due to CDC reopening guidance measures they adopted: (a) implementation of central air ventilation systems, (b) operation of the restaurants at $50 \%$ capacity, reducing the chances of close proximity with infected diners; (c) spacing out of dining tables to such that their physical distances were increased to minimize droplet transmission between diners, (d) requirement that employees use face masks at all time and patrons wear them when not eating or drinking to reduce airborne transmission of the virus.

The presence of SARS-CoV-2 vgRNA in the tablecloth surface sample suggests that a presymptomatic and/or asymptomatic individual(s) dined in the restaurants during our samplings, and they shed the virus on the tablecloth. Our result agrees well with the positive surface samples collected from rooms with asymptomatic patients (Wei et al., 2020) and the detection of virus 
from asymptomatic patients' exhaled breath (Riediker and Tsai, 2020). Importantly, the positive surface sample was collected from a disposable plastic tablecloth immediately after use and prior to cleaning. In Restaurant $A$, all tables and chairs were cleaned and sanitized after use. In Restaurant B, all tables were covered by a new plastic tablecloth, and after use the tablecloth was promptly discarded; further, the table and chair surfaces were cleaned and disinfected using an EPA-approved disinfectant (U.S. EPA, 2020) containing $58 \%(\mathrm{v} / \mathrm{v}$ ) ethanol and $0.1 \%(\mathrm{w} / \mathrm{v}$ ) quaternary ammonium salts (active ingredient). The cleaning and disinfection process may be one major reason why other surface samples in public areas were all negative for SARS-CoV-2 vgRNA. Tablecloth surfaces can get contaminated by direct contact when an infected individual touches the surface with contaminated hands, or their exhaled droplets settle onto the surface. Since the air samples collected simultaneously with the positive surface sample tested negative for SARS-CoV-2 vgRNA by RT-PCR, the risk of airborne transmission was likely low in the restaurant. Additionally, we were unable to isolate the virus from cell cultures inoculated with aliquots of the positive surface sample, inferring the virus was not infectious (Dumont-Leblond et al., 2021) because the person was at the resolution phase of COVID-19. This is because infectious virus is typically shed during the earlier phase of COVID-19, but not during the later phase of the illness, wherein vgRNA can be detected in saliva or respiratory tract specimens but not viable (infectious) virus (Arons et al., 2020; Yamagishi et al., 2020).

All other surface samples that were tested in this work were negative for SARS-CoV-2, which may have been due to prompt and aggressive surface decontamination of each patron's eating area following their exit from the restaurants. Noteworthy, newer information from the CDC indicates that the principal mode by which people are infected by SARS-CoV-2 is through exposure to respiratory droplets carrying infectious virus (CDC, 2021b). Whereas it is possible for people to get infected through contact with contaminated surfaces or objects (fomites), the risk is considered low. Our finding of only one SARS-CoV-2 sample suggests the infection risk through fomite transmission is indeed low in restaurants following CDC reopening guidance. In the restaurants of this work, the employees cleaned and disinfected the high-touch surfaces very frequently, including the door handles, menus, and check-out bill holders. Moreover, the waiters and waitresses wore gloves while serving the food. Compared to the presence of SARS-CoV-2 in the surface samples collected from door handles of restaurants located in Massachusetts, U.S. earlier during the pandemic (March 2021) (Harvey et al., 2021b), we did not detect the virus in the door handles of the sampled restaurant. One possible reason may be the disinfection measures that were conducted in the sampled restaurants. The effect of disinfection has been validated in some environmental sampling studies performed in public transportation vehicles, such as buses and subway trains (Carloid et al., 2020; Moreno et al., 2021), resulting in negative surface samples at the locations following enhanced disinfection measures.

\subsection{Limitations}

Access to other restaurants for samplings was limited because of the difficulties in obtaining the permission from restaurant owners/managers during a pandemic. To evaluate the effectiveness of control strategies in reducing the transmission and to develop the most cost-effective way for the reopening, environmental surveillance in more restaurants in places with a wide variety of population densities to assess varied adopted reopening measures is needed. For example, the infection risk may be different amongst the restaurants operated at $100 \%$ capacity but had different distances between tables. In more densely populated areas, especially those with higher positive rates of COVID-cases in the community, the possibility of acquiring SARS-CoV-2 infections may also be different from our study, as more infected individuals may dine in the facilities and shed the virus. Furthermore, a well-designed network of samplers in restaurants without interfering with regular business operations was unrealistic due to the optics, sampler size and noise; nevertheless, we managed to use duplicate stationary samplers and personal samplers in expanding the sampled areas.

As new variants of SARS-CoV-2 are in circulation and some such as the 'delta' or "omicron" variants appear to be more contagious than previous strains (Harvey et al., 2021a), the detection of SARS-CoV-2 in restaurant environments need to be reevaluated. Some recent studies also showed that individuals infected with new variants of SARS-CoV-2 may shed greater amounts of 
virus per person (Mohandas et al., 2021; Shen et al., 2021); thus, it would be important to determine if the situation has changed and whether the risk for dining in restaurants is higher as new variants are circulating widely. Restaurants offering outdoor seating and private rooms may also be evaluated to identify whether the transmission risk may be lower in those spaces and thereafter make suggestions for restaurants reopening. Several studies detected the virus on surfaces that were infrequently touched in rooms with COVID-19 patients such as the top of door frames and the top of shelving units, indicating the importance of airborne transmission in spreading the virus (Dumont-Leblond et al., 2021). Therefore, future studies of no-touch surface samplings in restaurants are of interest to investigate the airborne transmission in the facilities, as direct or indirect transmission may be minimal for those surfaces.

\section{CONCLUSIONS}

Overall, our environmental surveillance study showed that the air and surface samples were negative for SARS-CoV-2, except one tablecloth surface sample that tested positive for vgRNA by RT-PCR. However, no virus was isolated from cell cultures inoculated with aliquots of that RT-PCR positive sample. The positive surface sample with non-infectious virus, along with RT-PCR negative samples, suggest that the transmission risk of SARS-CoV-2 might be low in restaurants that operate following $\mathrm{CDC}$ reopening guidance such as (a) implementation of proper ventilation systems, (b) reduction in the number of diners served, (c) adherence to physical distancing measures between patrons, (d) performance of surface disinfection procedures after diners leave, prior to seating of new patrons, and (e) enforcement of masking policies for those not eating or drinking. The relatively low number of COVID-19 cases in such a mid-scale city might have also contributed to the finding of only one positive sample. COVID-19 vaccines were not readily available during the performance period of this work. Our work suggests that by implementing proper infection control procedures, that risk of acquiring COVID-19 in indoor dining settings may be reduced.

\section{ACKNOWLEDGEMENTS}

This work was supported by National Science Foundation (Grant No. 2030844) and National Institutes of Health (Grants No. R44ES030649 and No. R01AI158868). The authors are grateful to the owners and managers of the restaurants for access and assistance in samplings. The authors thank Dr. William Lindsley (NIOSH) for free loan of the NIOSH bioaerosol samplers to us, Dr. David Kaplan from the University of Florida for loaning us the state-licensed truck for transporting the sampling system, and Dr. Katherine Deliz from the University of Florida for access to the freezer for sample storage. Any opinions, findings, and conclusions or recommendations expressed in this material are those of the authors and do not necessarily reflect the views of the National Science Foundation nor the National Institutes of Health.

\section{ADDITIONAL INFORMATION}

\section{Conflict of Interest}

The authors report no conflict of interest.

\section{REFERENCES}

Abrahão, J.S., Sacchetto, L., Rezende, I.M., Rodrigues, R.A.L., Crispim, A.P.C., Moura, C., Mendonça, D.C., Reis, E., Souza, F., Oliveira, G.F.G., Domingos, I., de Miranda Boratto, P.V., Silva, P.H.B., Queiroz, V.F., Machado, T.B., Andrade, L.A.F., Lourenço, K.L., Silva, T., Oliveira, G.P., de Souza Alves, V., et al. (2021). Detection of SARS-CoV-2 RNA on public surfaces in a densely populated urban area of Brazil: A potential tool for monitoring the circulation of infected patients. Sci. Total Environ. 766, 142645. https://doi.org/10.1016/j.scitotenv.2020.142645

Arons, M.M., Hatfield, K.M., Reddy, S.C., Kimball, A., James, A., Jacobs, J.R., Taylor, J., Spicer, K., 
Bardossy, A.C., Oakley, L.P., Tanwar, S., Dyal, J.W., Harney, J., Chisty, Z., Bell, M., Methner, M., Paul, P., Carlson, C.M., McLaughlin, H.P., Thornburg, N., et al. (2020). Presymptomatic SARSCoV-2 infections and transmission in a skilled nursing facility. N. Engl. J. Med. 382, 2081-2090. https://doi.org/10.1056/NEJMoa2008457

Ben-Shmuel, A., Brosh-Nissimov, T., Glinert, I., Bar-David, E., Sittner, A., Poni, R., Cohen, R., Achdout, H., Tamir, H., Yahalom-Ronen, Y., Politi, B., Melamed, S., Vitner, E., Cherry, L., Israeli, O., Beth-Din, A., Paran, N., Israely, T., Yitzhaki, S., Levy, H., et al. (2020). Detection and infectivity potential of severe acute respiratory syndrome coronavirus 2 (SARS-CoV-2) environmental contamination in isolation units and quarantine facilities. Clin. Microbiol. Infect. 26, 1658-1662. https://doi.org/10.1016/j.cmi.2020.09.004

Best Places (2021). Gainesville, Florida People. https://www.bestplaces.net/people/city/flor ida/gainesville (accessed 2 June 2021).

Blocken, B., van Druenen, T., van Hooff, T., Verstappen, P.A., Marchal, T., Marr, L.C. (2020). Can indoor sports centers be allowed to re-open during the COVID-19 pandemic based on a certificate of equivalence? Build. Environ. 180, 107022. https://doi.org/10.1016/j.buildenv.2020.107022

Carloid, P. Di, Chiacchiaretta, P., Sinjariid, B., Aruffo, E., Stuppia, L., De Laurenzi, V., Di Tomoid, P., Pelusi, L., Potenza, F., Veronese, A., Vecchiet, J., Falasca, K., Ucciferri, C. (2020). Air and surface measurements of SARS-CoV-2 inside a bus during normal operation. PLoS One 15, e0235943. https://doi.org/10.1371/journal.pone.0235943

CDC (2020). Considerations for Restaurants and Bars I COVID-19. CDC. https://www.cdc. gov/coronavirus/2019-ncov/community/organizations/business-employers/bars-restaurants. html (accessed 14 May 2021).

CDC (2021a). How Coronavirus Spreads. CDC. https://www.cdc.gov/coronavirus/2019-ncov /prevent-getting-sick/how-covid-spreads.html (accessed 10 May 2021).

CDC (2021b). Science Brief: SARS-CoV-2 and Surface (Fomite) Transmission for Indoor Community Environments. https://www.cdc.gov/coronavirus/2019-ncov/more/science-and-research/surfacetransmission.html (accessed 23 November 2021).

Chang, S., Pierson, E., Koh, P.W., Gerardin, J., Redbird, B., Grusky, D., Leskovec, J. (2020). Mobility network models of COVID-19 explain inequities and inform reopening. Nature 589, 82-87. https://doi.org/10.1038/s41586-020-2923-3

Cheng, V.C.C., Wong Mnurs, S.C., Chen, J.H.K., Yip, C.C.Y., Frcpath, V.W.M.C., Tsang, O.T.Y., Frcpath, S.S., Chan, J.F.W., Ho, P.L., Yuen, K.Y. (2020). Escalating infection control response to the rapidly evolving epidemiology of the coronavirus disease 2019 (COVID-19) due to SARSCoV-2 in Hong Kong. Infect. Control Hosp. Epidemiol. 41, 493-498. https://doi.org/10.1017/ice. 2020.58

Chia, P.Y., Coleman, K., Tan, Y.K., Ong, S.W.X., Gum, M., Lau, S.K., Sutjipto, S., Lee, P.H., Son, T.T., Young, B., Milton, D., Gray, G., Schuster, S., Barkham, T., De, P.P., Vasoo, S., Chan, M., Ang, B.S.P., Tan, B.H., Leo, Y.S., et al. (2020). Detection of air and surface contamination by severe acute respiratory syndrome coronavirus 2 (SARS-CoV-2) in hospital rooms of infected patients. Public Health 2020.03.29.20046557. https://doi.org/10.1101/2020.03.29.20046557

Dumont-Leblond, N., Veillette, M., Bhérer, L., Boissoneault, K., Mubareka, S., Yip, L., Dubuis, M.E., Longtin, Y., Jouvet, P., McGeer, A., Duchaine, C. (2021). Positive no-touch surfaces and undetectable SARS-CoV-2 aerosols in long-term care facilities: An attempt to understand the contributing factors and the importance of timing in air sampling campaigns. Am. J. Infect. Control 49, 701-706. https://doi.org/10.1016/j.ajic.2021.02.004

Fisher, K.A., Tenforde, M.W., Feldstein, L.R., Lindsell, C.J., Shapiro, N.I., Files, D.C., Gibbs, K.W., Erickson, H.L., Prekker, M.E., Steingrub, J.S., Exline, M.C., Henning, D.J., Wilson, J.G., Brown, S.M., Peltan, I.D., Rice, T.W., Hager, D.N., Ginde, A.A., Talbot, H.K., Casey, J.D., et al. (2020). Community and close contact exposures associated with COVID-19 among symptomatic adults $\geq 18$ years in 11 outpatient health care facilities - United States, July 2020. MMWR Morb. Mortal. Wkly. Rep. 69, 1258-1264. https://doi.org/10.15585/mmwr.mm6936a5

Guo, M., Xu, P., Xiao, T., He, R., Dai, M., Miller, S.L. (2021). Review and comparison of HVAC operation guidelines in different countries during the COVID-19 pandemic. Build. Environ. 187, 107368. https://doi.org/10.1016/j.buildenv.2020.107368

Guy, G.P. (2021). Association of state-issued mask mandates and allowing on-premises restaurant dining with county-level COVID-19 case and death growth rates - United States, 
March 1-December 31, 2020. MMWR Morb. Mortal. Wkly. Rep. 70, 350-354. https://doi.org/ 10.15585/mmwr.mm7010e3

Hadei, M., Mohebbi, S.R., Hopke, P.K., Shahsavani, A., Bazzazpour, S., Alipour, M., Jafari, A.J., Bandpey, A.M., Zali, A., Yarahmadi, M., Farhadi, M., Rahmatinia, M., Hasanzadeh, V., Nazari, S.S.H., Asadzadeh-Aghdaei, H., Tanhaei, M., Zali, M.R., Kermani, M., Vaziri, M.H., Chobineh, H. (2021). Presence of SARS-CoV-2 in the air of public places and transportation. Atmos. Pollut. Res. 12, 302-306. https://doi.org/10.1016/j.apr.2020.12.016

Harvey, A.P., Fuhrmeister, E.R., Cantrell, M.E., Pitol, A.K., Swarthout, J.M., Powers, J.E., Nadimpalli, M.L., Julian, T.R., Pickering, A.J. (2021). Longitudinal monitoring of SARS-CoV-2 RNA on high-touch surfaces in a community setting. Environ. Sci. Technol. Lett. 8, 168-175. https://doi.org/10.1021/acs.estlett.0c00875

Harvey, W.T., Carabelli, A.M., Jackson, B., Gupta, R.K., Thomson, E.C., Harrison, E.M., Ludden, C., Reeve, R., Rambaut, A., Peacock, S.J., Robertson, D.L. (2021). SARS-CoV-2 variants, spike mutations and immune escape. Nat. Rev. Microbiol. 19, 409-424. https://doi.org/10.1038/s41 579-021-00573-0

Kim, J., Lee, J.C. (2020). Effects of COVID-19 on preferences for private dining facilities in restaurants. J. Hosp. Tour. Manage. 45, 67-70. https://doi.org/10.1016/j.jhtm.2020.07.008

Kwon, K.S., Park, J.I., Park, Y.J., Jung, D.M., Ryu, K.W., Lee, J.H. (2020). Evidence of long-distance droplet transmission of SARS-CoV-2 by direct air flow in a restaurant in Korea. J. Korean Med. Sci. 35, e415. https://doi.org/10.3346/jkms.2020.35.e415

Lednicky, John A, Shankar, S.N., Elbadry, M.A., Gibson, J.C., Alam, M.M., Stephenson, C.J., Eiguren-Fernandez, A., Glenn Morris, J., Mavian, C.N., Salemi, M., Clugston, J.R., Wu, C.Y. (2020a). Collection of SARS-CoV-2 virus from the air of a clinic within a university student health care center and analyses of the viral genomic sequence. Aerosol Air Qual. Res. 20, 11671171. https://doi.org/10.4209/aaqr.2020.05.0202

Lednicky, John A., Lauzard, M., Fan, Z.H., Jutla, A., Tilly, T.B., Gangwar, M., Usmani, M., Shankar, S.N., Mohamed, K., Eiguren-Fernandez, A., Stephenson, C.J., Alam, M.M., Elbadry, M.A., Loeb, J.C., Subramaniam, K., Waltzek, T.B., Cherabuddi, K., Morris, J.G., Wu, C.Y. (2020b). Viable SARS-CoV-2 in the air of a hospital room with COVID-19 patients. Int. J. Infect. Dis. 100, 476482. https://doi.org/10.1016/j.ijid.2020.09.025

Lednicky, J.A., Cherabuddi, K., Tagliamonte, M.S., Elbadry, M.A., Subramaniam, K., Waltzek, T.B., Morris, J.G. (2021a). In-frame 12-nucleotide deletion within open reading frame 3a in a SARSCoV-2 strain isolated from a patient hospitalized with COVID-19. Microbiol. Resour. Announce. 10, e00137-21. https://doi.org/10.1128/MRA.00137-21

Lednicky, J., Salemi, M., Subramaniam, K., Waltzek, T.B., Sabo-Attwood, T., Loeb, J.C., Hentschel, S., Tagliamonte, M.S., Marini, S., Alam, M.M., Stephenson, C.J., Elbadry, M., Jr, J.G.M. (2021b). Earliest detection to date of SARS-CoV-2 in Florida: Identification together with influenza virus on the main entry door of a university building, February 2020. PLoS One 16, e0245352. https://doi.org/10.1371/journal.pone.0245352

Lednicky, J.A., Lauzardo, M., Alam, M.M., Elbadry, M.A., Stephenson, C.J., Gibson, J.C., Morris, J.G. (2021c). Isolation of SARS-CoV-2 from the air in a car driven by a COVID patient with mild illness. Int. J. Infect. Dis. 108, 212-216. https://doi.org/10.1016/j.ijid.2021.04.063

Lei, H., Ye, F., Liu, X., Huang, Z., Ling, S., Jiang, Z., Cheng, J., Huang, X., Wu, Q., Wu, S., Xie, Y., Xiao, C., Ye, D., Yang, Z., Li, Y., Leung, N.H.L., Cowling, B.J., He, J., Wong, S.S., Zanin, M. (2020). SARSCoV-2 environmental contamination associated with persistently infected COVID-19 patients. Influenza Other Respi. Viruses 14, 688-699. https://doi.org/10.1111/irv.12783

Li, Y., Qian, H., Hang, J., Chen, X., Cheng, P., Ling, H., Wang, S., Liang, P., Li, J., Xiao, S., Wei, J., Liu, L. (2020). Probable airborne transmission of SARS-CoV-2 in a poorly ventilated restaurant. Build. Environ. 196, 107788. https://doi.org/10.1016/j.buildenv.2021.107788

Liu, H., Shen, L., Hong, J. (2021). Simulation-based study of COVID-19 outbreak associated with air-conditioning in a restaurant. Phys. Fluids 33, 23301. https://doi.org/10.1063/5.0040188

Liu, Yuan, Ning, Z., Chen, Y., Guo, M., Liu, Yingle, Gali, N.K., Sun, L., Duan, Y., Cai, J., Westerdahl, D., Liu, X., Xu, K., Ho, K. fai, Kan, H., Fu, Q., Lan, K. (2020). Aerodynamic analysis of SARS-CoV-2 in two Wuhan hospitals. Nature 582, 557-560. https://doi.org/10.1038/s41586-020-2271-3

Lu, J., Gu, J., Gu, J., Li, K., Xu, C., Su, W., Lai, Z., Zhou, D., Yu, C., Xu, B., Yang, Z. (2020). COVID-19 outbreak associated with air conditioning in restaurant, Guangzhou, China, 2020. Emerg. Infect. 
Dis. 26, 1628-1631. https://doi.org/10.3201/eid2607.200764

Ma, J., Qi, X., Chen, H., Li, X., Zhang, Z., Wang, H., Sun, L., Zhang, L., Guo, J., Morawska, L., Grinshpun, S.A., Biswas, P., Flagan, R.C., Yao, M. (2021). Coronavirus Disease 2019 Patients in Earlier Stages Exhaled Millions of Severe Acute Respiratory Syndrome Coronavirus 2 Per Hour. Clin. Infect. Dis. 72, e652-e654. https://doi.org/10.1093/cid/ciaa1283

Maestre, J.P., Jarma, D., Yu, J.R.F., Siegel, J.A., Horner, S.D., Kinney, K.A. (2021). Distribution of SARS-CoV-2 RNA signal in a home with COVID-19 positive occupants. Sci. Total Environ. 778, 146201. https://doi.org/10.1016/j.scitotenv.2021.146201

Mohandas, S., Yadav, P.D., Nyayanit, D., Deshpande, G., Shete-Aich, A., Sapkal, G., Kumar, S., Jain, R., Kadam, M., Kumar, A., Patil, D.Y., Sarkale, P., Gawande, P., Abraham, P. (2021). Comparison of the pathogenicity and virus shedding of SARS CoV-2 VOC 202012/01 and D614G variant in hamster model. bioRxiv. https://doi.org/10.1101/2021.02.25.432136

Moreno, T., Pintó, R.M., Bosch, A., Moreno, N., Alastuey, A., Minguillón, M.C., Anfruns-Estrada, E., Guix, S., Fuentes, C., Buonanno, G., Stabile, L., Morawska, L., Querol, X. (2021). Tracing surface and airborne SARS-CoV-2 RNA inside public buses and subway trains. Environ. Int. 147, 106326. https://doi.org/10.1016/j.envint.2020.106326

Nelson, E.J., McKune, S.L., Ryan, K.A., Lednicky, J.A., Crowe, S.R., Myers, P.D., Morris, J.G. (2021). SARS-CoV-2 positivity on or after 9 days among quarantined student contacts of confirmed cases. JAMA 325, 1561-1562. https://doi.org/10.1001/jama.2021.2392

Oran, D.P., Topol, E.J. (2020). Prevalence of asymptomatic SARS-CoV-2 infection a narrative review. Ann. Intern. Med. 173, 362-367. https://doi.org/10.7326/M20-3012

Pan, M., Bonny, T.S., Loeb, J., Jiang, X., Lednicky, J.A., Eiguren-Fernandez, A., Hering, S., Fan, Z.H., $\mathrm{Wu}$, C.Y. (2017). Collection of viable aerosolized influenza virus and other respiratory viruses in a student health care center through water-based condensation growth. mSphere 2, e00251-17. https://doi.org/10.1128/mSphere.00251-17

Zhu, N., Zhang, D., Wang, W., Li, X., Yang, B., Song, J., Zhao, X., Huang, B., Shi, W., Lu, R., Niu, P., Zhan, F., Ma, X., Wang, D., Xu, W., Wu, G., Gao, G.F., Tan, W. (2020). A novel coronavirus from patients with pneumonia in China, 2019. N. Engl. J. Med. 382, 727-733. https://doi.org/10.10 56/NEJMoa2001017

Rahmani, A.R., Leili, M., Azarian, G., Poormohammadi, A. (2020). Sampling and detection of corona viruses in air: A mini review. Sci. Total Environ. 740, 140207. https://doi.org/10.1016/j.s citotenv.2020.140207

Riediker, M., Tsai, D.H. (2020). Estimation of Viral Aerosol Emissions From Simulated Individuals With Asymptomatic to Moderate Coronavirus Disease 2019. JAMA Netw. Open 3, e2013807. https://doi.org/10.1001/jamanetworkopen.2020.13807

Santarpia, J.L., Rivera, D.N., Herrera, V.L., Morwitzer, M.J., Creager, H.M., Santarpia, G.W., Crown, K.K., Brett-Major, D.M., Schnaubelt, E.R., Broadhurst, M.J., Lawler, J.V., Reid, S.P., Lowe, J.J. (2020). Aerosol and surface contamination of SARS-CoV-2 observed in quarantine and isolation care. Sci. Rep. 10, 12732. https://doi.org/10.1038/s41598-020-69286-3

Santos, D. (2020). How the Food and Beverage Industry is Responding to Coronavirus. https://www.aislelabs.com/blog/2020/04/06/how-the-food-and-beverage-industry-isresponding-to-coronavirus-updated-frequently/ (accessed 18 May 2021).

Schaller, M.A., Sharma, Y., Dupee, Z., Nguyen, D., Urueña, J., Smolchek, R., Loeb, J.C., Machuca, T.N., Lednicky, J.A., Odde, D.J., Campbell, R.F., Sawyer, W.G., Mehrad, B. (2021). Ex vivo SARSCoV-2 infection of human lung reveals heterogeneous host defense and therapeutic responses. JCI Insight 6, e148003. https://doi.org/10.1172/jci.insight.148003

Shen, X., Tang, H., Pajon, R., Smith, G., Glenn, G.M., Shi, W., Korber, B., Montefiori, D.C. (2021). Neutralization of SARS-CoV-2 variants B.1.429 and B.1.351. N. Engl. J. Med. 384, 2352-2354. https://doi.org/10.1056/nejmc2103740

Statista (2021). U.S. COVID-19 cases by state. https://www.statista.com/statistics/1102807 /coronavirus-covid19-cases-number-us-americans-by-state/ (accessed 25 June 2021).

Sung, Y.K., Hu, H.H.S., King, B. (2021). Restaurant preventive behaviors and the role of media during a pandemic. Int. J. Hosp. Manage. 95, 102906. https://doi.org/10.1016/j.ijhm.2021.102906

Texas Medical Association (2020). TMA Chart Shows COVID-19 Risks for Various Activities. https://www.texmed.org/TexasMedicineDetail.aspx?Pageid=46106\&id=54216 (accessed 14 October 2020). 
U.S. EPA (2020). About List N: Disinfectants for Coronavirus (COVID-19). https://www.epa.g ov/coronavirus/about-list-n-disinfectants-coronavirus-covid-19-0 (accessed 22 June 2021).

Wei, L., Lin, J., Duan, X., Huang, W., Lu, X., Zhou, J., Zong, Z. (2020). Asymptomatic COVID-19 patients can contaminate their surroundings: An environment sampling study. mSphere 5, 36. https://doi.org/10.1128/msphere.00442-20

Yamagishi, T., Ohnishi, M., Matsunaga, N., Kakimoto, K., Kamiya, H., Okamoto, K., Suzuki, M., Gu, Y., Sakaguchi, M., Tajima, T., Takaya, S., Ohmagari, N., Takeda, M., Matsuyama, S., Shirato, K., Nao, N., Hasegawa, H., Kageyama, T., Takayama, I., Saito, S., et al. (2020). Environmental sampling for severe acute respiratory syndrome coronavirus 2 during a COVID-19 outbreak on the diamond princess cruise ship. J. Infect. Dis. 222, 1098-1102. https://doi.org/10.1093/infdi s/jiaa437 